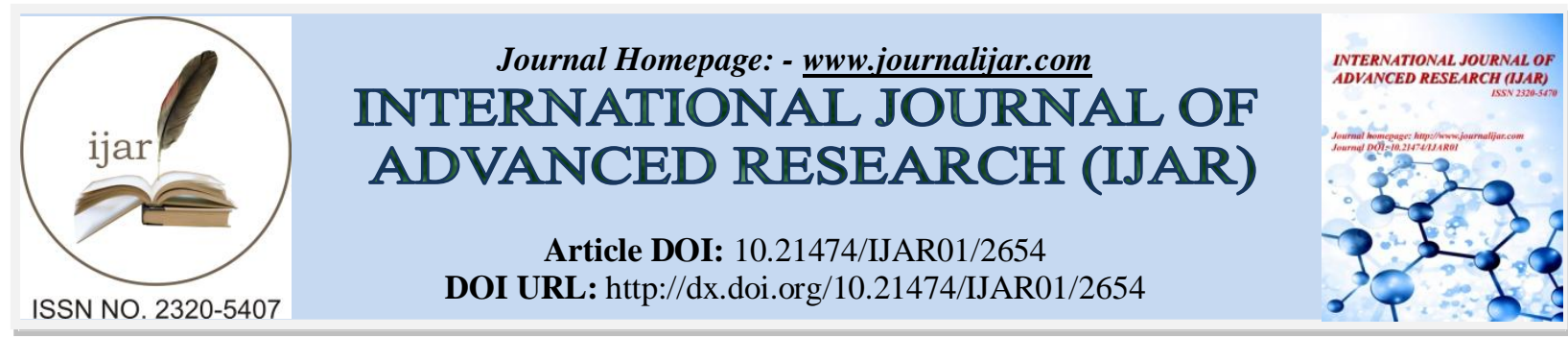

RESEARCH ARTICLE

\title{
SENSITIVITY OF PHYLLOSTICTA ZINGIBERI AGAINST CARBENDAZIM CAUSING LEAF SPOT OF GINGER.
}

J. M. Gorule and S. S. Kamble.

Mycology and Plant Pathology Laboratory, Department Of Botany, Shivaji University, Kolhapur. 416004

\section{Manuscript Info}

Manuscript History

Received: 30 October 2016

Final Accepted: 29 November 2016

Published: December 2016

Key words:-

Ginger, Phyllosticta zingiberi, Disease,

Leaf spot, Carbendazim.

\section{Abstract}

It was found that there was variation in the MIC of carbendazim among the 13 isolates of Phyllosticta zingiberi Ramkr. collected from different districts of Maharashtra (Kolhapur, Sangli, Satara), on both in vitro and in vivo. MIC on agar plates ranged from 2 to $9 \%$ and it was 2 to $8 \%$ on zingiber leaves. Isolate $\mathrm{Pz} 1$ was sensitive to carbendazim and it showed $2 \%$ MIC both in vitro and in vivo while isolate $\mathrm{Pz} 11$ was resistant to carbendazim and showed $9 \% \mathrm{MIC}$ on agar plates and $8 \%$ on zingiber leaves.

Copy Right, IJAR, 2016,. All rights reserved.

\section{Introduction:-}

Ginger (Zingiber officinale Roscoe.) belongs to family Zingiberaceae, its rhizome is widely used as a spice or a medicine. Ginger is indigenous to south China, and was spread eventually to the spice Islands, other parts of Asia (including India) and subsequently to West Africa and the Caribbean. India is now the largest producer of ginger. In India it is cultivated in Maharashtra, Krnataka, Orissa, Assam, Meghalaya, Arunachal Pradesh, Gujarat, etc. Ginger suffers from many diseases and cause substantial yield loss to ginger production. Leaf spot, caused by Phyllosticta zingiberi Ramkr., is one of the most threatening foliar disease and was reported for the first time in India by Ramakrishnan (1941). Symptoms are observed on leaves as oval to elongated spots that later turn whitish spots surrounded by dark brown margin with yellowish hallo (Ramakrishnan, 1941).The present investigation is carried out to determine the minimum inhibitory concentration of carbendazim for effective disease management.

\section{Material and Method:-}

13 samples exhibiting leaf spot of ginger were collected from different districts of Maharashtra viz. Kolhapur (Mudal Titta, Majnal, Kolhapur, Mhalunge, Mangnur), Sangli (Jambhali, Zelam, Islampur, Vadiye Raybag, Tandulwadi) and Satara (Dahiwadi, Koregaon, Jaitapur).To isolate the causal agent, the collected samples were brought to the laboratory in sterilized bags. The infected portion of leaf is cut in to the size $2 \mathrm{~mm}$ and sterilized by using $0.1 \% \mathrm{HgCl}_{2}$ and washed with sterilized distilled water (Jadhav et al., 2010), these sterilized leaf portion were kept on a czapek dox agar plates amended with streptomycin sulphate (Patil et al., 2012; Mali et al., 2015). Inoculated plates were incubated at $28 \pm 2^{0} \mathrm{C}$ for growth of the fungus and further studies (Mali et al., 2016). After 9-10 days of culture, grayish fungal mass was observed. On the basis of morphological, microscopic characters and following relevant mycological literature the fungal isolate was identified as Phyllosticta zingiberi Ramkr. In this manner, 13 isolates were obtained.

The in vitro sensitivity of Phyllosticta zingiberi was carried out by using Food Poisoning Technique (Dekker and Gielink, 1979). Czapek Dox agar medium plates were prepared containing different concentrations of carbendazim.. After solidification of media, a disc $(8 \mathrm{~mm})$ with fungal culture was obtained from the margin of an actively 
growing colony and placed upside down on the agar surface. These plates were then incubated at $28-30^{\circ} \mathrm{C}$ in 12 hour cycle of dark and light and then continuous growth was measured after various time intervals. Plates without carbendazim was served as control.

For in vivo experiments Mycelial suspensions of all fungal isolate were prepared in sterile distilled water, and then inoculated on the healthy leaves of Zingiber officinale treated with $10 \mathrm{ml}$ solution of different concentrations of carbendazim 24 hours before the inoculation. The experiment was carried out in triplicates. The plants without fungicide treatment served as control. The plants without any treatment served as absolute control.

Table 1:- MIC (Minimum Inhibitory Concentration) of carbendazim against Phyllosticta zingiberi isolates causing Leaf spot of Zingiber officinale.

\begin{tabular}{|c|c|c|c|}
\hline Locality & Isolate & in vitro (\%) & in vivo (\%) \\
\hline Mudal titta & $\mathrm{Pz} \mathrm{1}$ & 2 & 4 \\
\hline Majnal & $\mathrm{Pz} \mathrm{2}$ & 5 & 2 \\
\hline Kolhapur & $\mathrm{Pz} \mathrm{3}$ & 3 & 5 \\
\hline Mangnur & $\mathrm{Pz} \mathrm{4}$ & 6 & 4 \\
\hline Mhalunge & $\mathrm{Pz} \mathrm{5}$ & 6 & 3 \\
\hline Jambhli & $\mathrm{Pz} \mathrm{6}$ & 3 & 5 \\
\hline Zelam & $\mathrm{Pz} \mathrm{7}$ & 5 & 3 \\
\hline Islampur & $\mathrm{Pz} \mathrm{8}$ & 7 & 8 \\
\hline Dahivadi & $\mathrm{Pz} 9$ & 4 & 6 \\
\hline Koregaon & $\mathrm{Pz} \mathrm{10}$ & 9 & 6 \\
\hline Jaitapur & $\mathrm{Pz} \mathrm{11}$ & 7 & \\
\hline Vadiye Raybag & $\mathrm{Pz} \mathrm{12}$ & 8 & \\
\hline Tandulwadi & $\mathrm{Pz} \mathrm{13}$ & 5 & \\
\hline
\end{tabular}

\section{Result and Discussion:-}

There was variation in the minimum inhibitory concentration of carbendazim. MIC on agar plates ranged from 2 to 9 $\%$ and it was 2 to $8 \%$ on zingiber leaves. Isolate $\mathrm{Pz} 1$ was sensitive to carbendazim and it showed $2 \%$ MIC both in vitro and in vivo While isolate $\mathrm{Pz} 11$ was resistant to carbendazim and showed $9 \% \mathrm{MIC}$ on agar plates and $8 \%$ on zingiber leaves. The results are in agreement with other workers also. Mane (2009) reported MIC of carbendazim against Alternaria tenussima causing leaf spot of Taro which is ranged from 4 to $8.5 \%$ in vitro and 100 to 20,000 $\mu \mathrm{g} / \mathrm{ml}$ in vivo. Similarly, Bhale (2009) reported the MIC of carbendazim against Alternaria alternata causing leaf spot of spinach was ranging from 350 to $700 \mu \mathrm{g} / \mathrm{ml}$. Similarly Sutar (2010) found that MIC of carbendazim against Alternaria alternata causing leaf spot of gerbera was ranging from 10-15\% both in vitro and in vivo. According to Khandare (2013) the MIC of carbendazim among 12 isolates of Alternaria alternata causing root rot of fenugreek was ranging from 2500 to $5000 \mu \mathrm{g} / \mathrm{ml}$ in vitro and 500 to $1000 \mu \mathrm{g} / \mathrm{ml}$ in vivo.

\section{References:-}

1. Bhale, U. N., Rajkonda, J. N. and Sarwade, P. P. (2009): Evaluation of botanicals against Alternaria spinaceae causing leaf spot of spinach (Spinacea oleracea L.), Geobios, 36:125-128.

2. Dekker, J. and Gielink, A. J. (1979): Acquired resistance to pimaricin in Cladosprium f. sp. Narcissi associated with decreased virulence. Neth. J. Pl. Pathol. 85: 67-73.

3. Khandare, N. K. and Kamble, S. S. (2013): Sensitivity of carbendazim against Alternaria alternata causing root rot of Fenugreek, Bioinfolet 10 (1 B): 307 - 308, 2013.

4. Mali, A. M., Patil, V. B., Ade, A. B., Chavan, N. S. And Kamble, S. S. (2015): First Report Of Fusarium Sp. FIESC_17 On Cucumis trigonus In India. Plant Disease. 10.1094/PDIS -09 -14 -0881 -PDN. http://dx.doi.org/10.1094/PDIS -09 -14 -0881 -PDN .

5. Mali, A. M., Patil, V. B., Pise, N. M. and Ade, A. B. (2016): First Report of Leaf Spot Caused by Fusarium sp. NFCCI 2882 on Angiopteris evecta: A King Fern from Western Ghats, India. Plant Disease.

6. Mane, M. J. and Kamble, S. S. (2009): Studies on management of Taro leaf spot, M. Phil. Dissertation, Shivaji University, Kolhapur.

7. Patil, V. B., Mali, A. M., Mahamuni, R. J., Chavan, N. S. And Kamble, S. S. (2012): First Report Of Leaf Spot Caused By Phoma Costarricensis on Delphinium Malabaricum In Western Ghats Of India. Plant Disease. 96:1074. 10.1094/PDIS -12 -11 -1012 -PDN. http://dx.doi.org/10.1094/PDIS -12 -11 -1012 -PDN. 
8. Ramkrishnan, T. S. (1941): A leaf spot disease of Zingiber officinale caused by Phyllosticta zingiberi N. SP., Proceedings of the Indian Academy of Sciences - Section B.15(4), pp 167-171.

9. Sutar, M. A. and Kamble, S. S. (2010): Studies on chemical management of leaf spot of gerbera, , M. Phil. Dissertation, Shivaji University, Kolhapur.

10. Jadhav, D. Y., Sahoo, A. K., Ghosh, J. S., Ranveer, R. C. and Mali, A. M. (2010): Phytochemical Detection and in vitro Evaluation of Tamarind Fruit Pulp for Potential Antimicrobial Activity. International Journal of Tropical Medicine. 5(3): 68-72. DOI: 10.3923/ijtmed.2010.68.72. 